\title{
Landasan Filosofis Keterampilan Komunikasi Konseling
}

\author{
Rezki Hariko \\ Jurusan Bimbingan dan Konseling, Fakultas Ilmu Pendidikan, Universitas Negeri Padang, \\ Jl. Prof. Dr. Hamka, Padang, Sumatera Barat, Indonesia 25131 \\ E-mail: hariko@konselor.org
}

Artikel diterima: 18 Januari 2017; direvisi 4 Mei 2017; disetujui 4 Mei 2017

\begin{abstract}
Counseling is a professional activity involving the relationship between a counselor with an individual or a group of individuals. Like an interpersonal relationship in general, in the process of counseling occurs the process of interaction and communication between individuals with other individuals (counselors-counselee). Mastery of communication skills is a basic prerequisite for counselors to be able to use various counseling skills effectively and efficiently. It should be understood that almost all of the counseling skills involve the counselor's communication skills. A good understanding of communication skills should be based on an in-depth study and understanding of communication philosophy. Mastery of communication skills will facilitate the counselor in using various counseling skills that have been formulated by experts as assets to provide successful assistance services for the counselee.
\end{abstract}

Keywords: philosophical; communication skills; counseling

\begin{abstract}
Abstrak: Konseling merupakan kegiatan profesional yang melibatkan hubungan antara seorang konselor dengan individu atau sekelompok individu. Layaknya suatu hubungan interpersonal, konseling tidak dapat dilepaskan dari berlangsungnya proses interaksi dan komunikasi pada pihak-pihak yang terlibat di dalam proses tersebut. Penguasaan keterampilan komunikasi merupakan prasyarat dasar bagi konselor untuk dapat menggunakan berbagai keterampilan konseling secara efektif dan efisien. Harus dipahami bahwa hampir keseluruhan keterampilan konseling melibatkan keterampilan komunikasi konselor. Pemahaman yang baik terhadap keterampilan komunikasi harus didasari oleh pengkajian dan pemahaman mendalam terhadap filsafat komunikasi. Penguasaan tersebut memudahkan konselor dalam menggunakan berbagai keterampilan konseling yang telah dirumuskan oleh para ahli sebagai modal untuk memberikan pelayanan bantuan yang berhasil-guna bagi konseli.
\end{abstract}

Kata kunci: filosofis; keterampilan komunikasi; konseling

Konseling merupakan profesi yang hadir sebagai respon terhadap kebutuhan individu untuk memahami diri, lingkungan, serta hal lain yang terkait dengan kehidupannya. Konseling merupakan sebuah pekerjaan profesional yang dalam pelayanan ahlinya tidak hanya sekadar menerapkan seperangkat prosedur tetap, melainkan selalu berpikir dengan mengerahkan kemampuan akademik yang dikuasainya untuk melakukan layanan konseling (Radjah, 2016). Konseling sebagai suatu profesi, berkembang sejak awal tahun 1900-an, dengan kemunculan tiga tokoh utama dalam konseling, yaitu: Frank Parsons, Jesse B. Davis dan Clifford Beers (Gibson \& Mitchell, 2008; Gladding, 2012).

Pada era sekarang, konseling mengalami perkembangan yang sangat signifikan. Beberapa topik bahasan konseling yang menjadi tren terkini di antaranya bagaimana menghadapi kekerasan, trauma dan krisis, perawatan terorganisir, kesejahteraan, keadilan sosial, teknologi, kepemimpinan dan identitas. Di samping itu, konseling juga berhubungan dengan kesejahteraan, pertumbuhan pribadi, 
karier dan kelainan pada orang yang dianggap sehat dan memiliki masalah serius. Layanan konseling berbasis pada teori serta merupakan proses berupa perkembangan dan intervensi (Gladding, 2012).

Konseling merupakan salah satu cara khusus untuk membantu orang lain yang melibatkan keterampilan tertentu untuk tujuan-tujuan khusus (Geldard \& Geldard, 2005). Sebagai suatu ilmu, konseling beroperasi dengan memanfaatkan berbagai keterampilan tertentu berdasarkan pendekatan dan teori yang telah tervalidasi. Menurut Glanz (Hansen, Stevic \& Warner, 1982) konseling bersifat interdisipliner yang mengaplikasikan konsep-konsep dari ilmu psikologi, sosiologi, antropologi, pendidikan, ekonomi dan filsafat. Konseling sebagai suatu ilmu memiliki ikatan disipliner dengan bidang psikologi, sosiologi, antropologi, biologi, kesehatan dan ilmu lainnya (Gibson \& Mitchell, 2008).

Konseling sebagai suatu proses, melibatkan hubungan antara satu individu dengan individu lain, yaitu konselor dan konseli merupakan aspek terpenting yang harus ditekankan dalam memahami profesi ini (Hansen, Stevic, \& Warner, 1982). Hubungan ini merupakan sebuah proses profesional yang melibatkan dua pihak yang secara bersama-sama dan bersinergi, berusaha mencapai suatu tujuan bersama. Konseling merupakan suatu tipe hubungan khusus antara konselor dengan orang yang membutuhkan bantuannya (konseli), yang dapat berbentuk hubungan tatap muka, melalui telepon, surat-menyurat, ataupun dengan bantuan alat elektronik yang memiliki tujuan tertentu (Geldard \& Geldard, 2005). Kualitas hubungan antara konselor dan konseli tampaknya paling memungkinkan untuk menciptakan pertumbuhan hubungan antar keduanya (Corey, 2015). Dengan demikian, konseling melibatkan suatu hubungan profesional yang bersifat memberikan bantuan dan sangat bergantung pada kualitas kepribadian konselor.

Dalam penyelenggaraan praktik konseling, konselor mengandalkan penggunaan sejumlah keterampilan, salah satunya yaitu kemampuan berkomunikasi yang merupakan keterampilan mikro konseling, di samping berbagai keterampilan lainnya (Geldard \& Geldard, 2005). Menurut NelsonJones (2008) terdapat dua kategori utama keterampilan konseling, yaitu keterampilan komunikasi dan bertindak, serta keterampilan pikiran. Keterampilan komunikasi dan bertindak melibatkan perilaku eksternal, dan keterampilan pikiran melibatkan perilaku internal konselor. Keterampilan komunikasi merupakan salah satu keterampilan utama yang harus dikuasai oleh konselor untuk penyelenggaraan praktik konseling.

Pada prinsipnya, komunikasi merupakan hal yang paling esensial dalam kehidupan manusia, tidak hanya dalam proses konseling. Dengan komunikasi, individu mengekspresikan dirinya, membentuk jaringan sosial dan mengembangkan kepribadiannya (Zamroni, 2009). Kegagalan individu dalam berkomunikasi menghambat terciptanya saling pengertian, kerja sama, toleransi, dan menghambat terlaksananya norma-norma sosial. Demikian juga apabila dikaitkan dengan konseling, kegagalan atau kesuksesan proses komunikasi berpengaruh besar terhadap perkembangan hubungan konselor dan konseli, serta pengembangan diri dan pengentasan permasalahan konseli. Oleh karena itu, konselor secara berkelanjutan diharapkan dapat meningkatkan pemahaman dan penguasaan tentang keterampilan komunikasi. Pemahaman yang mendalam dapat diawali melalui pengkajian segala sesuatu tentang komunikasi dari sudut pandang filosofis.

Artikel ini membahas tentang konsep umum komunikasi, dasar filsafat komunikasi, komunikasi sebagai modal dasar hubungan interpersonal, dan komunikasi sebagai landasan keterampilan konseling. Tujuan pembahasan artikel secara umum adalah menyajikan wawasan tentang keterampilan komunikasi beserta kajian filsafat yang melandasinya. Secara khusus, artikel ini disajikan sebagai upaya menstimulasi konselor serta calon konselor untuk meningkatkan pemahaman dan penguasaan keterampilan komunikasi yang diperlukan agar dapat menyelenggarakan konseling secara efektif dan efisien.

\section{KONSEP UMUM KOMUNIKASI}

Komunikasi tidak dapat dipisahkan dari setiap aktifitas yang dijalani oleh individu. Eksistensinya jauh menembus ruang dan waktu, untuk tujuan yang sangat bervariasi dan menyentuh segala aspek kehidupan manusia. Para ahli menyebutkan lebih dari $80 \%$ alokasi waktu individu dalam satu hari 
dilakukan dengan berkomunikasi (Maulana \& Gumelar, 2013). Artinya, komunikasi merupakan salah satu kebutuhan dasar individu yang diperolehnya melalui interaksi dalam lingkungan sosial. Komunikasi menjembatani informasi dari individu ke individu lain atau kelompok.

Komunikasi merambah ke segala bidang kajian, merasuk, menjadi bagian penting dan bersenyawa dengan bidang tersebut. Proses persenyawaan yang sangat unik, karena menghasilkan wujud yang akan tidak sama dengan lainnya, tergantung dengan bidang yang menjadi wadahnya. Komunikasi menembus banyak disiplin ilmu (Rakhmat, 2000). Sebagai sebuah gejala perilaku, komunikasi dipelajari dan diaplikasikan pada disiplin ilmu psikologi, sosiologi, antropologi, konseling dan lain sebagainya.

Komunikasi yang juga dikenal sebagai retorika merupakan ilmu pertama mengenai pernyataan antar manusia yang berkembang di Yunani dan Romawi kemudian berkembang pada dua arah, satu arah menuju ke Jerman menjadi Publizistikwissenschaft yang disingkat Publisistik dan arah kedua menuju ke Amerika Serikat yang berwujud menjadi Communication Science (Effendy, 2003). Lebih lanjut disebutkan, retorika sendiri sampai sekarang masih dipraktikkan dalam segala bidang kehidupan, meskipun tidak dilandasi oleh hasil penelitian ilmu-ilmu baru. Dalam sejarahnya retorika merupakan bentuk minat filsafat terhadap komunikasi yang dijual oleh kelompok Sophist kepada orang-orang Yunani (Rakhmat, 2000). Lebih jauh dipaparkan, berbeda dengan sosiologi, filsafat meneliti komunikasi secara kritis dan dialektis.

Secara etimologis perkataan komunikasi berasal dari Bahasa Latin yaitu communicare yang berarti berpartisipasi atau memberitahukan (Zamroni, 2009). Komunikasi berarti penyampaian pesan oleh komunikator kepada komunikan (Effendy, 2003). Berdasarkan definisi yang dikemukakan ini dapat dijelaskan bahwa komunikasi berkaitan dengan penyampaian sesuatu berupa pesan ataupun pandangan dalam rangka mencari kesamaan pandangan.

Dictionary of Behavioral Science menyajikan enam pengertian komunikasi (Rakhmat, 2000). Keenam pengertian tersebut, yaitu: (1) penyampaian perubahan energi dari satu tempat ke tempat yang lain seperti dalam sistem saraf atau penyampaian gelombang-gelombang suara; (2) penyampaian atau penerimaan sinyal atau pesan oleh organisme; (3) pesan yang disampaikan; (4) proses yang dilakukan satu sistem untuk memengaruhi sistem yang lain melalui pengaturan sinyal-sinyal yang disampaikan; (5) pengaruh satu wilayah persona pada wilayah persona yang lain sehingga perubahan dalam satu wilayah menimbulkan perubahan yang berkaitan dengan wilayah lain; dan (6) pesan klien kepada pemberi terapi dalam psikoterapi.

Berdasarkan penjelasan yang telah dipaparkan, dapat diartikan bahwa komunikasi merupakan proses penyampaian pesan dari seorang individu kepada individu atau kelompok lain. Proses tersebut berupa penyampaian energi dari alat-alat indra ke otak. Proses tersebut melibatkan beberapa peristiwa, yaitu: peristiwa penerimaan dan pengolahan informasi; saling pengaruh di antara berbagai sistem dalam diri organisme dan di antara organisme.

\section{DASAR FILSAFAT KOMUNIKASI}

Setiap ilmu pengetahuan memiliki kajian filsafat tersendiri (Syam, 2010)(Susanto \& Astrid, 1976). Hal ini dapat dimaklumi karena memang pada prinsipnya semua ilmu pada masa lampau berpangkal pada ilmu filsafat. Filsafat merupakan usaha untuk memahami atau mengerti dunia dalam hal makna dan nilai-nilainya (Zamroni, 2009). Filsafat berusaha menjawab pertanyaan tentang asal mula dan sifat dasar alam semesta tempat manusia hidup serta apa yang merupakan tujuan hidupnya. Lebih lanjut dijelaskan bahwa filsafat bisa menggunakan bahan-bahan deskriptif yang disajikan bidang studi khusus dan melampaui deskripsi tersebut dengan menyelidiki atau menanyakan sifat dasar, nilai dan kemungkinannya.

Filsafat komunikasi menyumbang keterangan kearah opini publik temporal, serta membawa kemajemukan ke domain publik (Arnett, 2010). Filsafat komunikasi bergerak pada situasi tertentu, momen tertentu, dan memberikan kontribusi tertentu bagi opini publik. Filsafat komunikasi memungkinkan perbedaan pendapat dengan penulis dan filsafat itu sendiri. Sebagai sebuah konsep, 
komunikasi dan informasi sangat erat kaitannya yang juga menandai lebih dari makna konseptual biasa ketika digunakan dalam teori-teori sosial serta dalam teori filosofis tentang realitas dan kebenaran kehidupan sosial (Robillard, 2005). Informasi dan komunikasi yang merujuk pada objek dari realitas yang diamati, selanjutnya akan digambarkan sebagai ontologitas prosedural dari informasi.

Sebuah model komunikasi bukanlah menjadi masalah filsafat hanya karena bertujuan untuk kebijaksanaan (Heslep, 1998). Komunikasi yang berhubungan dengan kebijaksanaan praktis mungkin tidak lebih dari kata-kata nasihat ataupun kata-kata yang bersifat argumentatif semata. Ketika komunikasi yang bertujuan untuk memahami adalah diskursif, dia akan menyerupai pidato filosofis yang cenderung untuk membenarkan pemahamannya. Perbedaan utama antara penalaran praktis dan filosofis menyangkut berbagai jenis alasan bahwa mereka masing-masing merangkum. Sementara itu argumen praktis harus mencakup alasan fakta situasi tertentu dan konkret. Sesuatu yang bersifat filosofis tidak perlu menyertakan referensi kepada hal tertentu dan konkret.

Filsafat antar pribadi merupakan jenis dari komunikasi yang tidak hanya bersifat linguistik (Heslep, 1998). Pemahaman filosofis dapat dicapai melalui analisis konseptual, pengembangan teori makna, penyelidikan aturan inferensi dan bentuk argumen serta kritik dari argumen. Bagaimanapun, bahasa bukan satu-satunya subjek filsafat interpersonal. Filsafat tersebut juga terkait dengan hal-hal, pikiran, tindakan ataupun kemungkinan lainnya.

Pendidikan tentang komunikasi sangat penting sebagai dasar filsafat (Heslep, 1998). Beberapa alasan untuk pernyataan tersebut, yaitu: (1) filsafat dan komunikasi berbagi prinsip-prinsip dasar; (2) prinsip-prinsip dasar filsafat berbagi dengan pendidikan sehingga merupakan dasar yang mau tak mau bersifat mutlak, berlaku untuk pendidikan kapan pun dan dimana pun; dan (3) prinsipprinsip komunikasi adalah substantif serta regulatif bagi pendidikan. Komunikasi menopang dan mengembangkan kebebasan, pengetahuan, sarat tujuan, dan kekonsultatifan yang bersifat memfasilitasi pelaku, baik sebagai individu maupun sebagai anggota masyarakat. Komunikasi adalah sesuatu yang perlu dipelajari oleh setiap individu, untuk pengembangan diri.

Salah satu aliran filsafat yang paling banyak berkontribusi terhadap kajian komunikasi adalah filsafat pragmatisme dengan beberapa tokoh terkenalnya, yaitu: Donald Davidson (Dresneer, 2006), N. Weiner (Robillard, 2005), C. S. Peirce (Bregman, 2009), dan William James (Arnett, 2010), dengan karakteristik dan penekanan yang tidak identik. Aliran pragmatisme pada beberapa dekade terakhir, memperoleh minat yang sangat besar dalam studi tentang komunikasi. Sebagai salah seorang pendiri dari aliran pragmatisme dan bahasan utama semiotika modern, Peirce seringkali diabaikan oleh ilmuwan yang tertarik dengan ilmu komunikasi. Semiotika Peirce menempatkan penekanan pada isyarat proses kognitif individu (Bregman, 2009). Peirce mencela kecenderungan Cartesian yang lebih mengandalkan pada satu urutan argumentasi dan metode buatan dalam bidang filsafat. Peirce berpendapat, janganlah kita berpura-pura dalam filsafat tentang apa yang kita tidak ragu dalam hati kita (Bregman, 2009).

Peirce menegaskan filsafat tidak seharusnya dimulai dari ide murni yang diibaratkan sebagai pengalaman seorang gelandangan yang berpetualang di suatu jalanan tanpa adanya pemukiman manusia (Bregman, 2009). Tetapi filsafat harus dimulai dengan ide-ide yang akrab dan kompleks yang melekat dalam dialog manusia. Selanjutnya Peirce menjelaskan bahwa setiap interaksi komunikasi baik asertif maupun interogatif, terkait dengan sesuatu secara bersama oleh kedua pihak. Kerangka semiotika Peircean menekankan bahwa komunikasi secara samar-samar dan secara umum dapat digambarkan sebagai kompleksitas proses isyarat, dimana pihak-pihak yang terlibat mengacu pada materi tertentu, secara teoritis dikonseptualisasikan sebagai obyek, dengan efek atau konsekuensi tertentu, dirangkum oleh orang yang menginterpretasikan.

Sementara itu filsafat analitik yang dikembangkan oleh Davidson tentang komunikasi memberikan perhatian lebih terhadap bahasa dan menjadikannya sebagai cabang utama yang menempatkan pertanyaan sentral terhadap makna linguistik (Dresner, 2006). Aturan dasar yang dibutuhkan untuk memahami makna linguistik adalah bahwa makna linguistik merupakan komunikasi linguistik interpersonal. Asumsi utama yang disampaikan adalah bahwa bahasa pada 
dasarnya intersubjektif dan oleh karena itu makna linguitik harus benar-benar dapat sepenuhnya dikomunikasikan dalam interaksi linguistik interpersonal. Komunikasi memang didasarkan pada pengamatan empiris (Robillard, 2005). Ketika antar individu berkomunikasi, maka mereka secara efektif melakukannya melalui penggunaan bahasa dan/atau perangkat simbolik lainnya, seperti teks, gambar dan lainnya.

Berdasarkan uraian yang telah dipaparkan jelas tergambar mengenai dasar filsafat komunikasi. Bidang ini layak menjadi perhatian lebih karena berkaitan erat dengan aktifitas keseharian individu. Bagaimanapun setiap individu terlibat dalam hubungan interpersonal yang melibatkan pihak lain, baik secara individual ataupun kelompok. Dalam hubungan tersebut, setiap individu akan berinteraksi melalui komunikasi. Pemahaman terhadap filsafat komunikasi sangat diperlukan oleh setiap individu, utamanya bagi individu pengemban dan pelaksana profesi yang mengharuskan adanya interaksi dengan individu dan kelompok lain.

\section{KOMUNIKASI SEBAGAI MODAL DASAR HUBUNGAN INTERPERSONAL}

Komunikasi merupakan hal yang esensial, berpengaruh dan bahkan seringkali menjadi faktor penentu dalam kehidupan manusia. Komunikasi merupakan dasar dari eksistensi suatu masyarakat dan menentukan struktur masyarakat tersebut (Susanto \& Astrid, 1976). Komunikasi merupakan mekanisme ataupun alat dalam pengoperan rangsangan dalam masyarakat. Dengan mekanisme komunikasi, individu dapat memberitahukan dan menyebarkan apa yang dirasakan dan apa yang diinginkannya terhadap individu lain.

Melalui komunikasi, individu mengembangkan diri dan membangun hubungan dengan individu lain ataupun kelompok. Hubungan individu dengan individu lain akan menentukan kualitas hidup individu tersebut yang dimoderatori oleh efektifitas komunikasi yang digunakannya. Tubbs \& Moss (Rakhmat, 2000; Maulana \& Gumelar, 2013) menyatakan bahwa komunikasi yang efektif ditandai dengan timbulnya lima hal, yaitu: (1) pengertian, penerimaan yang cermat; (2) kesenangan, hubungan yang hangat, akrab dan menyenangkan; (3) memengaruhi sikap, bersifat persuasif; (4) hubungan yang makin baik; dan (5) tindakan, melahirkan tindakan yang dikehendaki.

Beberapa fungsi umum komunikasi, yaitu terkait dengan fungsi informatif, edukatif, persuasif, dan rekreatif (Yusup, 1989). Fungsi informatif mengacu pada memberi keterangan, data, atau fakta yang berguna dalam segala aspek kehidupan manusia. Di samping itu komunikasi juga berfungsi dalam mendidik masyarakat dalam mencapai kedewasaan. Secara persuasif komunikasi berfungsi sebagai alat untuk membujuk orang lain agar berperilaku sesuai dengan kehendak yang diinginan komunikator. Sedangkan fungsi hiburan dimaksudkan bahwa dengan komunikasi memungkinkan individu untuk menghibur individu lain.

Sehubungan dengan fungsi komunikasi sebagai alat persuasi, kemampuan komunikasi dapat digunakan sebagai alat untuk membujuk atau mengarahkan orang lain (Maulana \& Gumelar, 2013). Komunikasi melalui wujud bahasa dan tanda, memiliki kekuatan untuk memengaruhi dan mengajak orang lain sehingga mengikuti suatu gagasan, ajakan dan model tingkah laku yang ditampilkan oleh komunikator. Komunikasi sebagai alat persuasif merupakan fungsi yang sangat penting dalam hubungan interpersonal. Upaya agar orang lain mematuhi atau mengikuti apa yang diinginkan oleh komunikator, merupakan tujuan komunikasi yang paling umum dan paling sering digunakan (Morissan, 2013).

Terkait dengan bahasan komunikasi, faktor-faktor yang dapat menyuburkan hubungan interpersonal, yaitu: percaya; sikap suportif; dan sikap terbuka (Rakhmat, 2000). Dari ketiga faktor tersebut, faktor percaya merupakan yang terpenting karena sangat menentukan efektifitas komunikasi. Faktor percaya akan meningkatkan komunikasi interpersonal karena membuka saluran komunikasi, memperjelas pengiriman dan penerimaan informasi serta memperluas peluang komunikan untuk mencapai maksudnya. Sikap percaya dalam komunikasi akan berkembang apabila didasarkan pada penerimaan, empati dan kejujuran. Faktor percaya ini secara langsung akan terkait dengan sikap 
suportif dan sikap terbuka dalam komunikasi. Menurut Mc. Crosky, Larson \& Knapp (Efendy, 2003) komunikasi yang efektif dapat dicapai dengan mengupayakan ketepatan (accuracy) yang berderajat tinggi dan empati antara komunikator dan komunikan dalam setiap situasi.

Komunikasi dalam hubungan interpersonal pada hakikatnya dilandasi oleh beberapa tujuan. Tujuan-tujuan tersebut dapat saja disadari oleh individu, meskipun ada kalanya tidak disadari. Menurut Devito (Maulana \& Gumelar, 2013), dalam komunikasi interpersonal setidaknya memiliki lima tujuan utama. Kelima tujuan komunikasi interpersonal tersebut yaitu untuk:(1) proses belajar; (2) membangun hubungan; (3) memengaruhi; (4) bermain; dan (5) menolong. Melalui komunikasi, individu dapat memberikan upaya-upaya yang menenangkan, menghibur, memberi saran dan pertimbangan serta pandangan terhadap orang lain yang memerlukan. Hal ini seringkali digunakan oleh profesi-profesi yang berlandasakan pada upaya pemberian bantuan, seperti bimbingan konseling, psikologi dan sebagainya.

Komunikasi antar pribadi dapat dilakukan dengan penyampaian dan/atau penangkapan pesan dalam dua cara utama, yaitu pesan verbal dan nonverbal. Pesan verbal diwujudkan melalui bahasa/ linguistik dan pesan nonverbal tergambar melalui isyarat tubuh. Pesan verbal dalam komunikasi berkaitan dengan kata dan makna, serta berbahasa dan berfikir (Maulana \& Gumelar, 2003). Pesan nonverbal mencakup segala ungkapan yang disadari atau tidak disadari dalam bentuk gerak tubuh, isyarat, air muka, nada atau getaran suara, dan tarikan nafas. Dalam komunikasi interpersonal dan antar budaya, kedua jenis bentuk penyampaian pesan ini kadang-kadang menimbulkan sedikit keterbatasan dalam pemahaman. Tetapi hal ini biasanya dapat diatasi dengan pemahaman yang tinggi oleh masing-masing orang yang terlibat dalam komunikasi terhadap makna bahasa non verbal dan budaya.

\section{KOMUNIKASI SEBAGAI LANDASAN KETERAMPILAN KONSELING}

Konselor sebagai salah satu jenis profesi bantuan berada pada posisi yang sangat diminati pada dekade terakhir ini. Berbagai permasalahan yang muncul dalam tatanan kehidupan individu dan bermasyarakat menjadi salah satu alasan dari ketertarikan tersebut. Profesi ini secara profesional diselenggarakan oleh konselor yang bekerja secara perorangan ataupun kelompok. Konselor profesional merupakan seseorang yang menekuni salah satu jenis profesi penolong (helper) yang terlatih di bidang keterampilan konseling. Konseling adalah salah satu cara untuk membantu orang lain, tetapi ini merupakan cara khusus yang melibatkan penggunaan keterampilan-keterampilan tertentu untuk tujuan-tujuan tertentu/khusus pula (Geldard \& Geldard, 2005).

Tujuan utama menggunakan keterampilan konseling adalah untuk membantu konseli mengembangkan keterampilan pribadi dan inner strength (kekuatan batin) agar mereka dapat menciptakan kebahagiaan di dalam kehidupannya sendiri dan orang lain. Dengan demikian keterampilan konseling digunakan oleh para konselor profesional untuk membantu individu atau kelompok agar memiliki kemampuan secara mandiri memberdayakan dan menolong dirinya sendiri. Hal ini secara langsung berkaitan dengan tujuan akhir proses konseling.

Upaya konseli memberdayakan diri dan menolong diri tersebut dapat melalui wujud pengembangan diri maupun upaya melepaskan diri dari permasalahan yang sedang dialaminya. Tujuan utama konseling adalah menolong konseli untuk dapat berubah dalam cara berfikir dan/atau dalam tindakan mereka sehari-hari, sehingga terhindar dari konsekuensi-konsekuensi negatif (Geldard \& Geldard, 2005).

Pemakaian keterampilan konseling oleh konselor dibagi menjadi lima tujuan berbeda, yaitu: (1) supportive listening, memberi konseli perasaan dipahami dan diafirmasi; (2) mengelola situasi bermasalah; (3) problem management; (4) mengubah keterampilan-keterampilan buruk konseli yang menciptakan masalah bagi konseli; dan (5) mewujudkan perubahan falsafah hidup (Nelson-Jones, 2008). Tentunya kelima tujuan keterampilan konseling ini diselenggarakan oleh konselor dengan media komunikasi, baik melalui bahasa verbal dalam wujud penyampaian kalimat dan/atau katakata ataupun melalui isyarat tubuh atau bahasa nonverbal. Kedua jenis keterampilan komunikasi ini mendasari hampir keseluruhan penggunaan keterampilan-keterampilan konseling. 
Keterampilan konseling terbagi menjadi dua, yaitu keterampilan dasar dan keterampilan lanjutan (Capuzzi \& Gross, 2013). Keterampilan dasar konseling terdiri dari: (1) keterampilan penampilan, meliputi kontak mata, bahasa tubuh, jarak, tekanan suara, dan alur verbal; (2) keterampilan mendengar dasar, meliputi pengamatan terhadap konseli, perilaku verbal, dorongan, parafrasa dan membuat kesimpulan, refleksi perasaan, dan mengajukan pertanyaan; (3) keterampilan selfattending, meliputi kesadaran diri, humor, sikap non-judgemental terhadap diri, dan sikap nonjudgemental terhadap orang lain, asli dan konkret. Sementara itu keterampilan lanjutan terdiri dari: (1) keterampilan pemahaman dan penolakan (understanding \& challenging), meliputi empati tingkat tinggi, keterbukaan diri (self disclosure), konfrontasi, dan kesegeraan; (2) keterampilan perilaku, dan (3) keterampilan mengakhiri konseling.

Neukrug (2012) menguraikan terdapat empat pengelompokan utama keterampilan yang digunakan konselor dalam proses konseling, yaitu: (1) keterampilan dasar terdiri dari mendengarkan, empati dan pemahaman mendalam, serta diam; (2) keterampilan yang biasa digunakan terdiri dari pertanyaan, pengungkapan diri, pemodelan, afirmasi dan dorongan, serta menawarkan alternatif, memberikan informasi, dan memberikan saran; (3) keterampilan lanjutan yang biasa digunakan terdiri dari konfrontasi, penafsiran dan kolaborasi; (4) keterampilan konseling lanjutan dan spesialis terdiri dari penggunaan metafora, hipnosis, keterampilan strategis, metode restrukturisasi kognitif, narasi dan cerita, terapi sentuhan, paradoxical intention, bermain peran, berbagai teknik visualisasi, dan sebagainya. Secara implisit dapat di cermati bahwa sebagian besar keterampilan-keterampilan yang dikemukakan tersebut, melibatkan kemampuan konselor dalam berkomunikasi.

Salah satu bahasan yang lebih kongkret tentang penerapan sejumlah keterampilan komunikasi dikemukakan oleh Nelson-Jones (2008), yaitu: (1) komunikasi verbal; (2) komunikasi vokal; (3) komunikasi tubuh; (4) komunikasi sentuhan (touch communication); dan (5) komunikasi mengambil tindakan (taking action communication). Komunikasi verbal atau percakapan terdiri atas pesan-pesan yang dikirim oleh konselor kepada konseli dengan menggunakan kata-kata. Dimensi komunikasi verbal meliputi bahasa, isi, frekuensi pembicaraan, dan kepemilikan atas perbendaharaan kata-kata. Dimensi bahasa tidak hanya meliputi jenis bahasa, tetapi juga mencakup elemen seperti gaya bahasa formal dan/atau informal yang digunakan. Misalnya gaya bahasa konselor yang tepat merangsang terwujudnya proses konseling yang konstruktif. Sementara itu, dimensi isi merujuk pada aspek topik dan bidang permasalahan. Isi pembicaraan biasanya berfokus pada percakapan tentang diri sendiri, orang lain atau lingkungan, dan dimensi evaluatif percakapan. Ada kalanya frekuensi pembicaraan lebih didominasi oleh konselor, namun dalam situasi lain kadang didominasi oleh konseli. Dalam hal ini, konselor hendaknya mampu menggunakan perbendaharaan kata yang tepat dan memiliki analisis cermat terhadap perbendaharaan kata yang digunakan konseli (Nelson-Jones, 2008). Masing-masing perbendaharaan kata yang digunakan memiliki motif-motif tertentu.

Komunikasi vokal konselor dapat menyampaikan tentang apa yang sesungguhnya dirasakan dan seberapa responsif konselor secara emosional memahami perasaan konseli. Komunikasi vokal mencakup lima dimensi, yaitu: volume; artikulasi; nada; penekanan; dan kecepatan berbicara. Konselor hendaknya berkomunikasi dengan suara yang lembut, dapat didengar, dan nyaman didengar. Kejelasan komunikasi konselor tersebut juga bergantung pada pelafalan kata yang diucapkan serta kemahirannya dalam mengatur nada dan rentang pembicaraan. Konselor juga perlu mengatur penekanan-penekanan secara tepat terhadap kata-kata yang digunakan dalam merespon perasaan dan situasi emosional konseli. Kemudian, konselor juga harus mempertimbangkan kecepatan berbicara. Pembicaraan yang terlalu cepat dapat menyulitkan konseli dalam memahami, sebaliknya pembicaraan yang terlalu lambat akan memunculkan kebosanan konseli dalam mendengarkan. Konselor sesekali perlu untuk diam dan berhenti pada saat yang tepat, guna memberi ruang bagi konseli untuk berfikir (Nelson-Jones, 2008).

Komunikasi tubuh terdiri atas pesan-pesan yang dikirim oleh anggota tubuh, yaitu ekspresi wajah, tatapan, kontak mata, gestur, postur atau posisi tubuh, kedekatan secara fisik, pakaian dan cara berdandan. Ekspresi wajah konselor terutama melalui mata dan alis, merupakan wahana utama untuk menyampaikan pesan kepada konseli. Konselor dituntut memandang hanya pada wajah 
konseli dan senantiasa melakukan kontak mata dengan tepat. Cara pandang ini sekaligus untuk menampilkan ketertarikannya terhadap pembicaraan dan upaya mengumpulkan informasi facial. Dimensi eksternal dari komunikasi tubuh yang juga sangat penting dicermati yaitu pakaian dan cara berdandan. Hal ini berpengaruh terhadap pengungkapan diri konselor dan informasi tentang seberapa baik konselor mengurus diri sendiri. Kategori khusus dari komunikasi tubuh yaitu komunikasi sentuhan yang merupakan upaya mengirim pesan melalui sentuhan fisik. Beberapa hal yang perlu jadi perhatian terkait komunikasi sentuhan, yaitu bagian tubuh apa yang digunakan konselor untuk menyentuh, bagian tubuh konseli yang disentuh dan seberapa lembut atau tegas sentuhan tersebut. Terkait dengan jenis keterampilan komunikasi ini, perlu diperhatikan pertimbangan budaya yang dianut oleh masing-masing konseli. Komunikasi mengambil tindakan berupa pesan-pesan yang disampaikan konselor dalam situasi tidak bertatap muka, misalnya mengirimkan catatan tindak lanjut kepada konseli (Nelson-Jones, 2008).

Dari paparan tersebut, diperoleh gambaran yang luas tentang keterampilan komunikasi yang digunakan dalam penyelenggaraan konseling. Secara garis besar komunikasi tersebut melibatkan aspek verbal, vokal, tubuh, sentuhan dan tindakan, dengan penekanan-penekanan yang spesifik pada masing-masingnya. Keterampilan komunikasi konselor merupakan elemen utama dalam penyelenggaraan konseling. Penguasaan keterampilan komunikasi akan mendukung efektifitas penggunaan sejumlah keterampilan konseling lainnya dan sekaligus mendorong kesuksesan konselor dalam penyelenggaran konseling.

\section{SIMPULAN}

Konselor dihadapkan pada berbagai tantangan berupa tuntutan untuk membantu perkembangan dan pengembangan individu serta pengentasan permasalahan individu. Dalam upaya untuk menghadapi tantangan tersebut, sudah semestinya konselor memperkaya diri dengan kelengkapan penguasaan berbagai keterampilan penyelenggaraan konseling. Keterampilan-keterampilan tersebut merupakan hasil dari rumusan kajian ilmiah berbagai pendekatan yang bersumber dari multi disiplin keilmuan.

Penyelenggaraan konseling yang efektif memanfaatkan sejumlah keterampilan yang tepat dengan spesifikasi kebutuhan dan permasalahan konseli. Dalam hal ini, penguasaan keterampilan komunikasi oleh konselor secara langsung berkorelasi dengan efektifitas penggunaan sejumlah keterampilan konseling lainnya. Berbagai keterampilan komunikasi tersebut disusun ahli dengan berpijak pada dasar filosofi komunikasi individu, untuk diberdayakan dalam proses konseling efektif. Beberapa jenis keterampilan komunikasi konselor tersebut, meliputi: (1) komunikasi verbal; (2) komunikasi vokal; (3) komunikasi tubuh; (4) komunikasi sentuhan; dan (5) komunikasi mengambil tindakan.

Penguasaan berbagai keterampilan yang tepat menjadi garansi bagi kesuksesan penyelenggaraan konseling. Konselor dan calon konselor dituntut untuk menguasai sejumlah keterampilan konseling, sehingga penyelenggaraan konseling relevan dengan kebutuhan dan permasalahan konseli. Dalam hal ini, penguasaan keterampilan komunikasi oleh konselor merupakan sesuatu yang sangat urgen, karena terkait erat dan/atau menunjang efektifitas penggunaan keterampilan-keterampilan konseling lainnya. Penggunaan keterampilan konseling, khususnya keterampilan komunikasi, memberi peluang yang lebih besar terhadap harapan keberhasilan penyelenggaraan konseling dengan cara-cara yang lebih efektif dan efisien.

\section{DAFTAR RUJUKAN}

Arnett, R. C. (2010). Defining Philosophy of Communication: Difference and Identity. Qualitative Research Reports in Communication, 11(1), 57-62.https://doi.org/10.1080/17459430903581279

Astrid, P., \& Susanto, S. (1976). Filsafat Komunikasi. Bandung: Bina Cipta. 
Bergman, M. (2009). Experience, Purpose, and the Value of Vagueness: On C. S. Peirce's Contribution to the Philosophy of Communication. Communication Theory, 19(3), 248-277. https://doi.org/10.1111/j.1468-2885.2009.01343.x

Capuzzi, D., \& Gross, D. R. (2013). Introduction to The Counseling Profession. Routledge.

Corey, G. (2015). Theory and Practice of Counseling and Psychotherapy. Nelson Education.

Dresner, E. (2006). Davidson's Philosophy of Communication. Communication Theory, 16(2), 155172. https://doi.org/10.1111/j.1468-2885.2006.00266.x

Effendy, O. U. (2003). Ilmu, Teori dan Filsafat Komunikasi. Bandung, PT Citra Aditya Bakti.

Geldard, K., \& Geldard, D. (2005). Practical Counselling Skills: An Integrative Approach. Palgrave Macmillan.

Gladding, S. T. (2012). Counseling: A Comprehensive Profession. New Jersey: Pearson Higher Ed.

Hansen, J. C., Stevic, R. R., \& Warner, R. W. (1982). Counseling: Theory and Process (Vol. 23). Allyn \& Bacon.

Heslep, R. D. (1998). Communication as The Absolute Foundation of Philosophy. Educational Theory, 48(1), 21-32. https://doi.org/10.1111/j.1741-5446.1998.00021.x

Maulana, H., \& Gumelar, G. (2013). Psikologi Komunikasi dan Persuasi. Jakarta: Akademia Pratama.

Morissan, M. A. (2010). Psikologi Komunikasi. Bogor: Ghalia Indonesia.

Nelson-Jones, R. (2008). Introduction to Counselling Skills: Text and Activities. Sage.

Neukrug, E. (2011). The World of The Counselor: An Introduction to The Counseling Profession. Nelson Education.

Radjah, C. L. (2016). Keterampilan Konseling Berbasis Metakognisi. Jurnal Kajian Bimbingan dan Konseling, 1(3), 90-94. Diambil dari http://journal2.um.ac.id/index.php/jkbk/article/view/613

Rahmat, J. (2000). Psikologi Komunikasi. Bandung: Remaja Rosda Karya.

Robillard, J. (2005). Cosmos and History. Cosmos and History: The Journal of Natural and Social Philosophy (Vol. 1). Cosmos Pub. Cooperative. Diambil dari http://www.cosmosandhistory.org/ index.php/journal/article/view/15

Syam, N. W. (2010). Filsafat Sebagai Akar Ilmu Komunikasi. Bandung: Simbiosa Rekatama Media.

Yusup, P. M. (1989). Komunikasi Pendidikan dan Komunikasi Instruksional. Bandung: Remaja Rosdakarya.

Zamroni, M. (2009). Filsafat Komunikasi: Pengantar Ontologis, Epistemologis, Aksiologis. Yogyakarta: Graha Ilmu. 